\title{
A Sensitive Determination of Acetaminophen in Pharmaceutical Preparations and Biological Samples using Multi-Walled Carbon Nanotube Modified Glassy Carbon Electrode
}

\author{
Ali Babaei, ${ }^{*, a, b}$ Mohammad Afrasiabi, ${ }^{a}$ Somaieh Mirzakhani ${ }^{a}$ and Ali Reza Taheri ${ }^{a}$ \\ ${ }^{a}$ Department of Chemistry and ${ }^{b}$ Research Center for Nanotechnology, University of Arak, \\ Arak, P.O. Box 38156-879, Iran
}

\begin{abstract}
Um eletrodo quimicamente modificado foi construído, baseado em eletrodo de carbono vítreo modificado por nanotubos de carbono de paredes múltiplas (ECV-NTCPM). O uso deste sensor na determinação de acetaminofeno (ACT), em meio aquoso tamponado, foi demonstrado. As medidas foram realizadas com utilização dos métodos de voltametria de pulso diferencial (VPD), voltametria cíclica (VC) e cronoamperometria (CA). A aplicação de VPD mostrou dois intervalos dinâmicos lineares. O primeiro intervalo dinâmico linear foi de 0,1 a $22 \mu \mathrm{mol} \mathrm{L} \mathrm{L}^{-1}$, com equação de calibração $\operatorname{Ip}(\mu \mathrm{A})=1,2782 \mathrm{c}\left(\mu \mathrm{mol} \mathrm{L}{ }^{-1}\right)+0,2431$

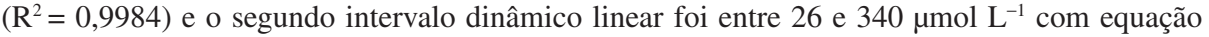
de calibração $\operatorname{Ip}(\mu \mathrm{A})=0,7793 \mathrm{c}\left(\mu \mathrm{mol} \mathrm{L} \mathrm{L}^{-1}\right)+11,615\left(\mathrm{R}^{2}=0,9986\right)$. O limite de detecção de $0,029 \mu \mathrm{mol} \mathrm{L}^{-1}(\mathrm{~S} / \mathrm{N}=3)$ foi obtido. O eletrodo modificado mostrou respostas eletroquímicas com alta sensitividade, excelente seletividade e estabilidade para determinação de ACT em condições ótimas, o que o torna um sensor adequado para detecção submicromolar de ACT em soluções. O desempenho analítico deste sensor foi avaliado para detecção de ACT em soro humano, urina humana e em preparações farmacêuticas com resultados satisfatórios.
\end{abstract}

A chemically modified electrode is constructed based on multi-walled carbon nanotube modified glassy carbon electrode (MWCNTs/GCE). It was demonstrated that this sensor could be easily used for determination of acetaminophen (ACT) in aqueous buffered media. The measurements were carried out by application of differential pulse voltammetry (DPV), cyclic voltammetry (CV) and chronoamperometry (CA) methods. Application of DPV method showed two linear dynamic ranges. The first linear dynamic range was from 0.1 to $22 \mu \mathrm{mol} \mathrm{L} \mathrm{L}^{-1}$, with a calibration equation of $\operatorname{Ip}(\mu \mathrm{A})=1.2782 \mathrm{c}(\mu \mathrm{mol} \mathrm{L}-1)+0.2431\left(\mathrm{R}^{2}=0.9984\right)$ and the second linear dynamic range was between 26 to $340 \mu \mathrm{mol} \mathrm{L}{ }^{-1}$ with a calibration equation of $\operatorname{Ip}(\mu \mathrm{A})=0.7793 \mathrm{c}\left(\mu \mathrm{mol} \mathrm{L}{ }^{-1}\right)+11.615$ $\left(\mathrm{R}^{2}=0.9986\right)$. A detection limit of $0.029 \mu \mathrm{mol} \mathrm{L} \mathrm{L}^{-1}(\mathrm{~S} / \mathrm{N}=3)$ was obtained. The modified electrode showed electrochemical responses with high sensitivity, excellent selectivity and stability for ACT determination at optimal conditions, which makes it a suitable sensor for submicromolar detection of ACT in solutions. The analytical performance of this sensor has been evaluated for detection of ACT in human serum, human urine and a pharmaceutical preparation with satisfactory results.

Keywords: acetaminophen, carbon nanotube, modified glassy carbon, electrochemical sensor

\section{Introduction}

Acetaminophen ( $N$-acetyl- $p$-aminophenol) (ACT), also known as paracetamol, is a drug with antipyretic and analgesic action, frequently used in therapy and which has low toxicity when used at the recommended doses. ${ }^{1}$ Nevertheless, the ease with which ordinary people can access this drug makes it frequently associated with overdoses, in

*e-mail: a-babaei@araku.ac.ir, a_babaei07@yahoo.com this situation causing serious or even fatal hepatic damage. ${ }^{2}$ An overdose of ACT can lead to the accumulation of toxic metabolites, which may cause severe and some times fatal hepatoxicity and nephrotoxicity ${ }^{3-5}$ and it can also cause liver disorders, skin rashes and inflammation of the pancreas. ${ }^{6}$ The product of hydrolytic degradation of ACT is 4-aminophenol which can be found in pharmaceutical preparations as a degradation product of ACT or as a synthetic intermediate which can be dangerous and causes teratogenic effect and nephrotoxicity. ${ }^{7}$ Controlling the amount of ACT in a given 
pharmaceutical formulation is vital in the quality control of the pharmaceutical industry, and can have a significant impact in healthcare quality. Various methods such as capillary electrophoresis, ${ }^{8,9}$ amperometric batch injection analysis, ${ }^{10}$ colorimetry ${ }^{11}$ titrimetry, ${ }^{12}$ FTIR and Raman spectrometry, ${ }^{13}$ flow injection analysis (FIA) using different methods of detection, ${ }^{12,14,15}$ liquid chromatography, ${ }^{16-18}$ spectrophotometry ${ }^{19-22}$ and chemiluminescence ${ }^{23}$ have been employed in the determination of ACT in pharmaceutical preparations and biological fluids. However, the majority of these methods suffer from some disadvantages such as high costs, long analysis times and requirement for sample pretreatment, and in some cases low sensitivity and selectivity that makes them unsuitable for routine analysis. Therefore, development of a simple, inexpensive, sensitive and accurate analytical method for determination of ACT is of great importance. ACT is an electroactive compound which can be oxidized electrochemically. The development and application of electrochemical sensors for ACT analysis, with respect to its sensitivity, accuracy, and simplicity, has been of greater interest in recent years. ${ }^{24-46}$ Careful studies of the reported articles revealed that apart from the variation of the electrochemical methods, there is a need to improve the electrochemical techniques with respect to their sensitivity, linear dynamic range or limit of detection.

Carbon nanotubes (CNT) represent an increasingly important group of nanomaterials with unique geometrical, mechanical, electronic and chemical properties. ${ }^{47,48}$ Such properties of CNT make them also extremely attractive for the task of electrochemical detection.

In this work we present the application of the multiwalled carbon nanotube modified glassy carbon electrode (MWCNTs/GCE) as a sensor for determination of ACT in buffer solutions at the biological $\mathrm{pH}$. This study has led to the development of a voltammetric method with good characteristics, such as simplicity of electrode preparation, high selectivity, wide linear dynamic range, and low detection limit. Finally the analytical performance of this sensor for determination of ACT in human serum, human urine and a pharmaceutical preparation samples is evaluated.

\section{Experimental}

\section{Reagents and solutions}

All chemicals were analytical grade and used without further purification. ACT and multi-walled carbon nanotubes (MWCNTs ) (> 95 wt.\%, 5-20 nm) were obtained from Merck and PlasmaChem GmbH companies, respectively. Stock standard solutions of $10 \mathrm{mmol} \mathrm{L}^{-1}$ ACT were freshly prepared in $0.1 \mathrm{~mol} \mathrm{~L}^{-1}$ phosphate buffers of $\mathrm{pH}$ 7. All subsequent ACT solutions were prepared by diluting the stock standard solutions using $0.1 \mathrm{~mol} \mathrm{~L}^{-1}$ phosphate buffer (pH 7). $0.1 \mathrm{~mol} \mathrm{~L}^{-1}$ phosphate buffer solution (PBS) was prepared by dissolving appropriate amounts of sodium hydrogen phosphate and sodium dihyrogen phosphate in $250 \mathrm{~mL}$ volumetric flask. Electrochemical experiments on the ACT were carried out in $0.1 \mathrm{~mol} \mathrm{~L}^{-1} \mathrm{PBS}$ at $\mathrm{pH} 7$.

Fresh human serum samples were obtained from the Razi Institute of Vaccine and Serum Company (Tehran, Iran). The serum and urine sample were filtered and diluted 100 times with $0.1 \mathrm{~mol} \mathrm{~L}^{-1} \mathrm{PBS}$ of $\mathrm{pH} 7$ and checked for the determination of the recovery by spiking the ACT. Ten tablets of Tylenol (McNeil-PPC Inc.,USA); (each labeled as containing $500 \mathrm{mg}$ of ACT ) were accurately weighed and powdered in a mortar. An amount equivalent to one tablet was dissolved in $70 \mathrm{~mL}$ of $0.1 \mathrm{~mol} \mathrm{~L}^{-1} \mathrm{PBS}(\mathrm{pH} \mathrm{7)}$ ). After sonication for $10 \mathrm{~min}$, the solution was filtered, the residue was washed three times with $10 \mathrm{~mL}$ of the buffer solvent, and the filtered volume was adjusted to $100 \mathrm{~mL}$ with the same solvent. This solution was diluted 1000 times for ACT determination with $0.1 \mathrm{~mol} \mathrm{~L}^{-1} \mathrm{PBS}$ of $\mathrm{pH}$ 7. The solution was used for the determination of the recovery efficiency.

\section{Instrumentation}

All the voltammetric measurements were carried out using a nanotube modified glassy carbon electrode (MWCNTs/GCE) as a working electrode, an $\mathrm{Ag} / \mathrm{AgCl} /\left(3 \mathrm{~mol} \mathrm{~L}^{-1}\right) \mathrm{KCl}$ as a reference electrode and platinum wire as an auxiliary electrode. DPV, CV and CA experiments were carried out using an Autolab PGSTAT 30 Potentiostat Galvanostat (EcoChemie, The Netherlands) coupled with a 663 VA stand (Metrohm Switzerland). All potentials given are with respect to the potential of the reference electrode. The $\mathrm{pH}$ measurements were made with a Metrohm 744 pH meter using a combination glass electrode.

\section{Modification of the electrodes}

A glassy carbon electrode (GCE, $3 \mathrm{~mm}$ diameter, Metrohm) was polished with 0.3 and $0.05 \mu \mathrm{m}$ aluminum slurry and rinsed thoroughly with triply distilled water. The GC electrode was individually cleaned by ultrasonic agitation for $5 \mathrm{~min}$ in ethanol and then distilled water. The electrode was then dried under nitrogen gas flow.

A stock solution of $1 \mathrm{mg} \mathrm{mL}{ }^{-1}$ MWCNTs-DMF was prepared by dispersing $1 \mathrm{mg}$ of MWNTs in $1 \mathrm{~mL}$ DMF. $30 \mu \mathrm{L}$ of MWCNTs-DMF solution was casted on electrode surface. The electrode was dried at room temperature to obtain MWCNTs/GCE. 
The fabricated MWCNTs/GCE was placed in the electrochemical cell containing $0.1 \mathrm{~mol} \mathrm{~L}^{-1} \mathrm{PBS}(\mathrm{pH} 7)$ and several cycles in the potential range of 0.1 to $0.7 \mathrm{~V}$ were applied using $\mathrm{CV}$ method to obtain stable responses. The electrochemical surface area of the modified MWCNTs/GCE and bare GCE were determined by cyclic voltammogram measured between -0.1 to $0.6 \mathrm{~V}$ in ferricyanide solution $\left(0.1 \mathrm{~mol} \mathrm{~L}^{-1}\right.$ phosphate buffer, $\mathrm{pH}$ 7.0) at different scan rates (not shown). The modified MWCNTs/GCE showed surface area of 9.8 times of GCE.

\section{General procedure}

Solutions $(10 \mathrm{~mL})$ containing the appropriate amounts of ACT in $0.1 \mathrm{~mol} \mathrm{~L}^{-1} \mathrm{PBS}$ at $\mathrm{pH} 7$ were transferred into the voltammetric cell. The voltammograms were recorded by applying positive-going potential from 0.2 to $0.6 \mathrm{~V}$. The voltammogram showed an anodic peak around $0.32 \mathrm{~V}$ corresponding to the oxidation of ACT compound with height proportional to its concentration in solution. The calibration curves were obtained by plotting anodic peak currents of ACT versus the corresponding concentrations. All experiments were carried out under open circuit conditions.

After each measurement, the MWCNTs/GCE was regenerated by thoroughly washing the electrode successively with triply distilled water and then 5\% sodium hydroxide solution. Finally the electrode was rinsed carefully with distilled water to remove any adsorbate from electrode surface and to provide a fresh one for subsequent experiments.

\section{Results and Discussion}

\section{Cyclic voltammetric investigation of ACT on MWCNTs / GCE}

The recorded cyclic voltammogram for $50 \mu \mathrm{mol} \mathrm{L} \mathrm{L}^{-1}$ ACT using the MWCNTs/GCE is shown in Figure 1. The ACT showed a reversible redox peak with $\Delta \mathrm{Ep}$ equal to $0.028 \mathrm{~V}$, which is similar to a two electron redox reversible system. This phenomenon is in accordance with electrocatalytic behavior of MWCNTs.

The effect of potential scan rate on redox response of ACT was investigated in phosphate buffer ( $\mathrm{pH}$ 7.0) solution containing $50 \mu \mathrm{mol} \mathrm{L}{ }^{-1}$ ACT. Figure 2 shows the cyclic voltammograms of the modified electrode at different scan rates in potential range 0 to $0.65 \mathrm{~V}$. The anodic and cathodic peak currents of ACT were proportional to the scan rate over the range $10-280 \mathrm{mV} \mathrm{s}^{-1}$ (Figure 2A) indicating adsorptive properties of the electrochemical process. Moreover, the anodic peak currents were almost the same as the corresponding cathodic peak currents.

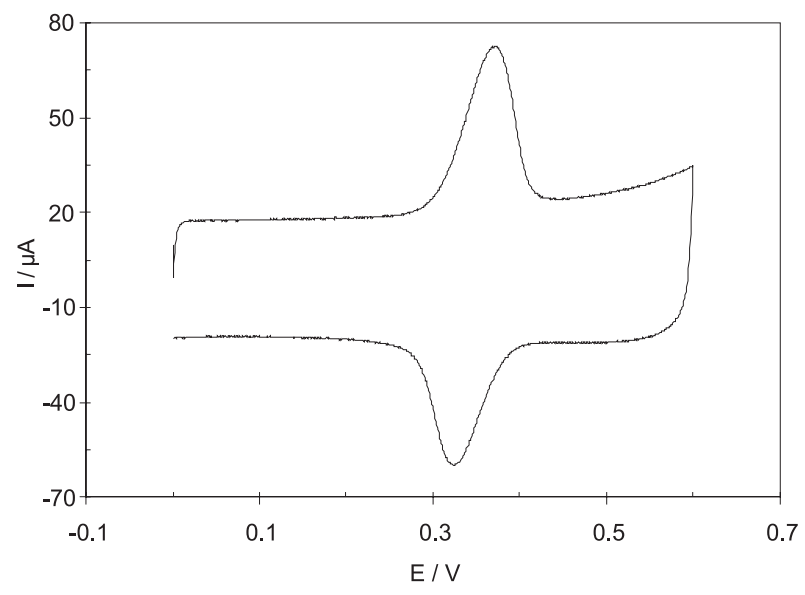

Figure 1. Cyclic voltammograms of $50 \mu \mathrm{mol} \mathrm{L} \mathrm{L}^{-1} \mathrm{ACT}$ at MWCNTs/GCE in $0.1 \mathrm{~mol} \mathrm{~L}^{-1}$ phosphate buffer solution $(\mathrm{pH} 7)$ at scan rate of $50 \mathrm{mVs}^{-1}$.

At sweep rates between $280 \mathrm{mV} \mathrm{s}^{-1}$ and $1000 \mathrm{mV} \mathrm{s}^{-1}$, the plot of peak currents $v s$. scan rate plot deviates from linearity and the peak current becomes proportional to the square root of the scan rate (Figure 2B), indicating a diffusion controlled process. At sweep rates higher than $100 \mathrm{mV} \mathrm{s}^{-1}$ peak separations $\left(\Delta \mathrm{E}_{\mathrm{p}}\right)$ begin to increase (Figure 2C), indicating the limitation due to charge transfer kinetics. Based on Laviron theory ${ }^{49}$ the electron transfer rate constant $\left(\mathrm{k}_{\mathrm{s}}\right)$ and charge transfer coefficient $(\alpha)$ can be determined by measuring the variation of $\Delta \mathrm{Ep} v s . \log$ scan rate. The slope of the $\Delta \mathrm{Ep} v s . \log (v)$, was about, $131.1 \mathrm{mV}$. Using the equation of:

$\mathrm{Ep}=\mathrm{K}-2.3030(\mathrm{RT} / \alpha \mathrm{nF}) \log (\mathrm{v})$

By considering two electrons transferred for ACT, charge transfer coefficient $(\alpha)$ of 0.562 was obtained. Introducing $\alpha$ value in the following equation, an apparent surface electron transfer rate constant, $\mathrm{k}_{\mathrm{s}}=2.558 \mathrm{~s}^{-1}$, was estimated.

$\log \mathrm{k}_{\mathrm{s}}=\alpha \log (1-\alpha)+(1-\alpha) \log \alpha-\log \left(\frac{\mathrm{RT}}{\mathrm{nFv}}\right)-\alpha(1-\alpha) \frac{\mathrm{nFE}}{2.3 \mathrm{RT}}$

The large value of electron transfer rate constant indicates high ability of MWCNTs for promoting electron transfer between ACT and the electrode surface. The surfaces of MWCNTs contain a large number of defects as well as special nanostructure of MWCNTs may act as molecular wires, enhance the direct electron transfer of $\mathrm{ACT}$ at MWCNTs.

\section{Electroxidation of ACT on MWCNTs /GCE}

The differential pulse voltammograms (DPV) recorded for ACT at bare GCE, and MWCNTs/GCE are shown in 

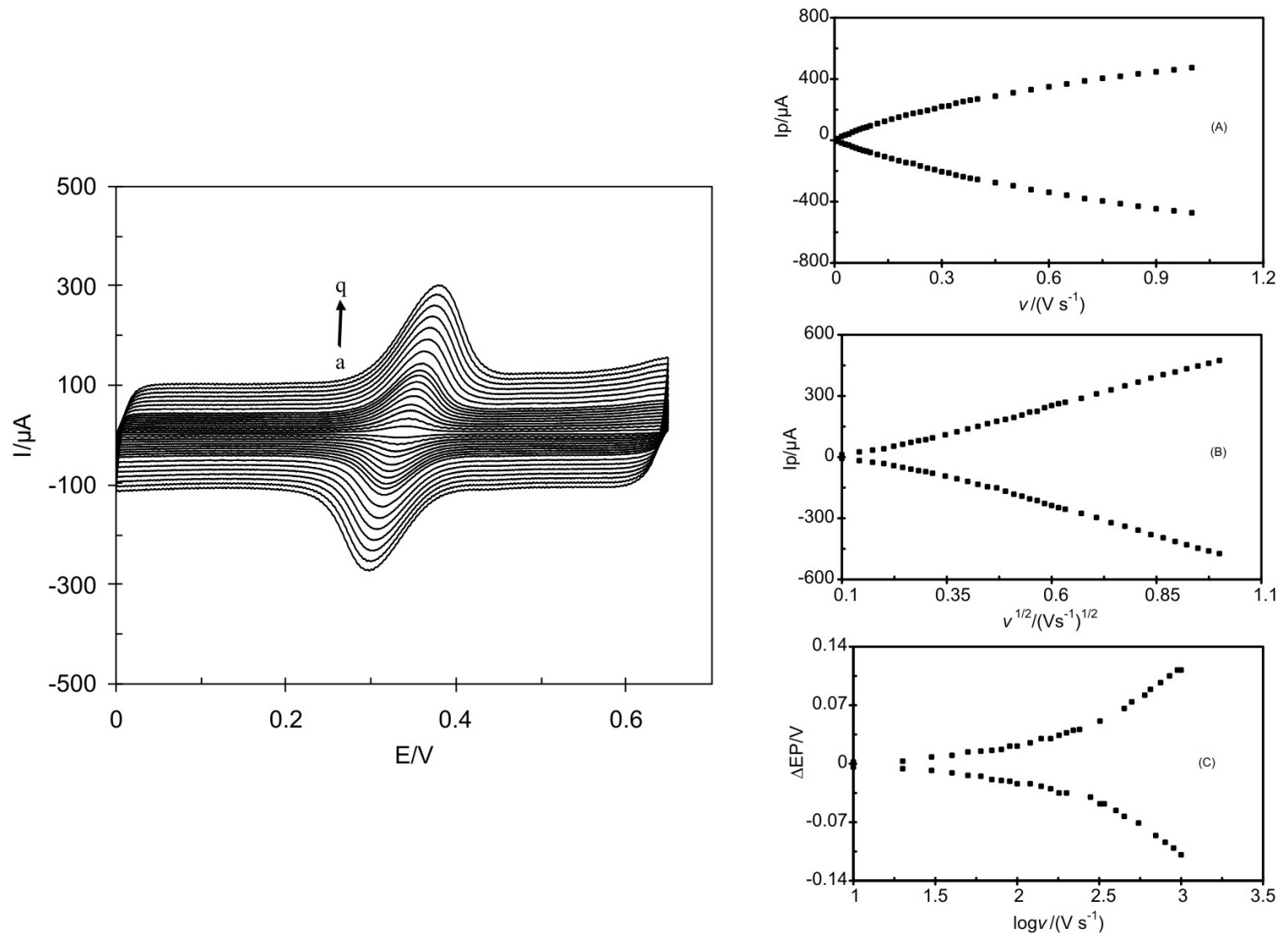

Figure 2. Effect of scan rate on the cyclic voltammograms peak currents of $50 \mu \mathrm{mol} \mathrm{L} \mathrm{L}^{-1} \mathrm{ACT}$ in phosphate buffer $(\mathrm{pH}$ 7) solution for different scan rate as (a) 10, (b) 20, (c) 30, (d) 40, (e) 50, (f) 60, (g) 70, (h) 80, (i) 90, (j) 100, (k) 120, (l) 140, (m) 160, (n) 180, (o) 200, (p) 220 and (q) 240 mVs ${ }^{-1}$. Insets: (A) Plot of peak currents as a function of scan rate of potential. (B) Plot of peak currents as a function of square root of the scan rate of potential. (C) Plot of peak separations currents as a function of logarithm of the scan rate of potential.

Figure 3. Curve a shows the voltammogram of $40 \mu \mathrm{mol} \mathrm{L}{ }^{-1}$ ACT in PBS (pH 7) at GC. Curve $b$ is a voltammogram of ACT obtained under the same conditions as curve $a$, at a MWCNTs /GCE. As can be seen, for the GC the oxidation peak for ACT is very small. However, the DPVs of

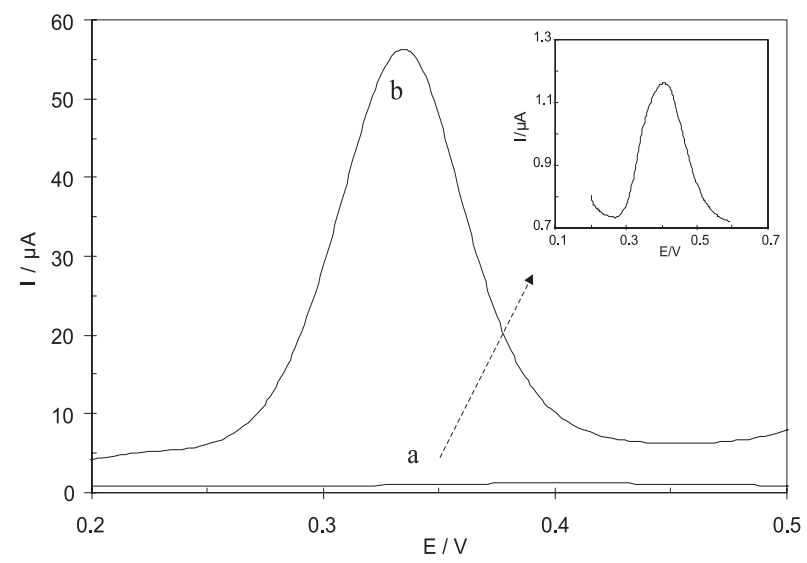

Figure 3. Differential pulse voltammograms of $40 \mu \mathrm{mol} \mathrm{L}^{-1}$ of ACT at (a) GC and (b) MWCNTs/GCE in $0.1 \mathrm{~mol} \mathrm{~L}^{-1}$ phosphate buffer solution (pH 7). Other conditions: Open circuit, $t=60 \mathrm{~s}$, pulse amplitude $=50 \mathrm{mV}$ and scan rate $=10 \mathrm{mV} \mathrm{s}^{-1}$, interval time $0.5 \mathrm{~s}$, modulation time $=0.2 \mathrm{~s}$ and step potential $=5 \mathrm{mV}$.
$\mathrm{ACT}$ at MWCNTs/GCE (curve b) showed considerable increases in its oxidation peak current. The presence of MWNTs could increase the surface area of the electrode and facilitate electron transfer between electrode and the analyte. Therefore the enhancements in the corresponding electrochemical oxidation peak currents were observed. Our electrochemical data showed that surface area of modified MWCNTs/GCE is 9.8 times of GCE. However, the oxidation peak current of ACT was increased upto 50 times, therefore the catalytic effect of MWCNTs is also responsible for increasing current.

\section{Effects of solution $p H$}

The effect of $\mathrm{pH}$ of solutions on the electrochemical response of the MWCNTs/GCE towards the determination of $50 \mu \mathrm{mol} \mathrm{L}^{-1} \mathrm{ACT}$ was investigated using $\mathrm{CV}$ method in $0.1 \mathrm{~mol} \mathrm{~L}^{-1}$ phosphate buffer solution. Variations of peak current with respect to $\mathrm{pH}$ of the electrolyte in the $\mathrm{pH}$ range from 3 to 10 are shown in Figure 4. It can be seen that the anodic peak currents of ACT increases with raising the solution $\mathrm{pH}$ until it reaches 7 (Figure 4, inset A). 


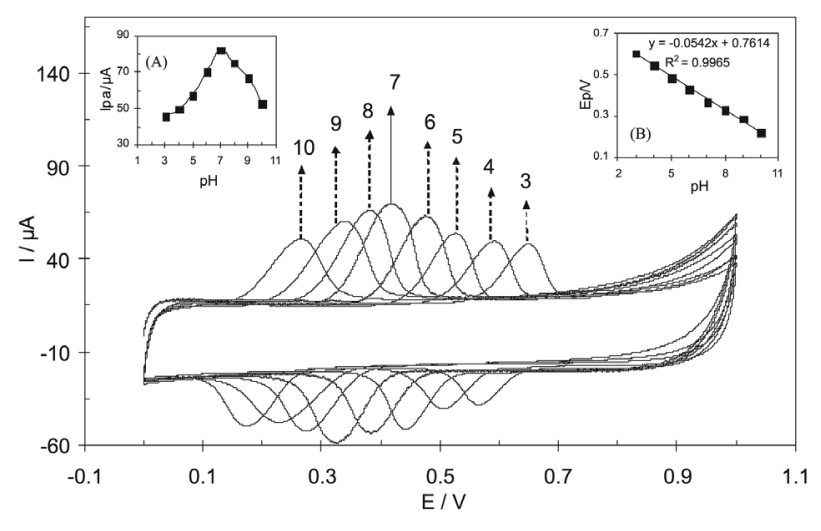

Figure 4. Effects of $\mathrm{pH}$ on the cyclic voltammogram oxidation peak current of $50 \mu \mathrm{mol} \mathrm{L} \mathrm{L}^{-1} \mathrm{ACT}$ at MWCNTs/GCE in phosphate buffer solutions at scan rate of $50 \mathrm{mVs}^{-1}$. Insets: (A) Plot of anodic peak currents (Ipa) as a function of $\mathrm{pH}$ of buffer solutions. (B) Plot of peak potentials (Ep) as a function of $\mathrm{pH}$ of buffer solutions.

However at higher $\mathrm{pH}$ the ACT oxidation peak current starts to diminish. Therefore the $\mathrm{pH}$ value of 7 , which is close to biological $\mathrm{pH}$ value, was chosen as an optimum solution $\mathrm{pH}$ for further experiments. Variation of ACT oxidation peak potential with $\mathrm{pH}$ is in accordance with equation of $\mathrm{Ep}=-0.0542 \mathrm{pH}+0.704$ (Figure 4, inset B). For a Nernstian process which numbers of transferred electrons are equal to number of transferred proton, the slope would be expected to be $-59 \mathrm{mV} \mathrm{pH}^{-1}$ unit. The $-54 \mathrm{mV} \mathrm{pH}^{-1}$ unit slope is in good agreement with other previously reported results. ${ }^{50-52}$ This suggests that the number of electrons and protons transferred in the redox reaction of $\mathrm{ACT}$ is equal.

\section{Effects of accumulation time}

Figure 5 shows plots of the anodic peak currents, obtained from $\mathrm{CV}$ experiments, versus accumulation time for $15 \mu \mathrm{mol} \mathrm{L}{ }^{-1}$ ACT. Initially, peak currents for this compound increase with accumulation time up to

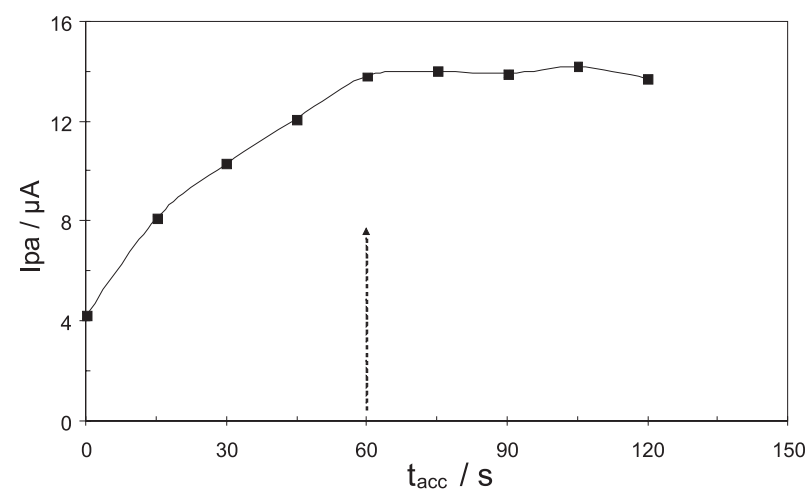

Figure 5. Effect of accumulation time on the cyclic voltammogram anodic peak currents of $15 \mu \mathrm{mol} \mathrm{L}^{-1} \mathrm{ACT}$ in phosphate buffer $(\mathrm{pH} 7)$ solution at scan rate of $50 \mathrm{mVs}^{-1}$.
$60 \mathrm{~s}$. However after $60 \mathrm{~s}$ the rate of increase falls away and it eventually reaches plateau. As a consequence, the accumulation time of $60 \mathrm{~s}$ was chosen as an optimum time for further experiments.

\section{Linear dynamic range and limit of detection of the method}

The electrochemical responses for consecutive addition of ACT to a $0.1 \mathrm{~mol} \mathrm{~L}^{-1} \mathrm{PBS} \mathrm{pH} 7$ using MWCNTs/GCE are depicted in Figures 6 and 7. Figure 6 show differential pulse voltammograms and corresponding calibration curves obtained at MWCNTs/GCE in various concentrations of ACT. By application of DPV method two linear ranges were obtained. The first linear dynamic range was from 0.1 to $22 \mu \mathrm{mol} \mathrm{L} \mathrm{L}^{-1}$, with a calibration equation of $\operatorname{Ip}(\mu \mathrm{A})=$ $1.2782 \mathrm{c}\left(\mu \mathrm{mol} \mathrm{L}{ }^{-1}\right)+0.2431\left(\mathrm{R}^{2}=0.9984\right)$ and the second linear dynamic range was between 26 to $340 \mu \mathrm{mol} \mathrm{L}^{-1}$ with a calibration equation of $\operatorname{Ip}(\mu \mathrm{A})=0.7793 \mathrm{c}\left(\mu \mathrm{mol} \mathrm{L}^{-1}\right)+$ $11.615\left(R^{2}=0.9986\right)$. A limit of detection of $0.029 \mu \mathrm{mol} \mathrm{L}^{-1}$ $(\mathrm{S} / \mathrm{N}=3)$ was obtained.

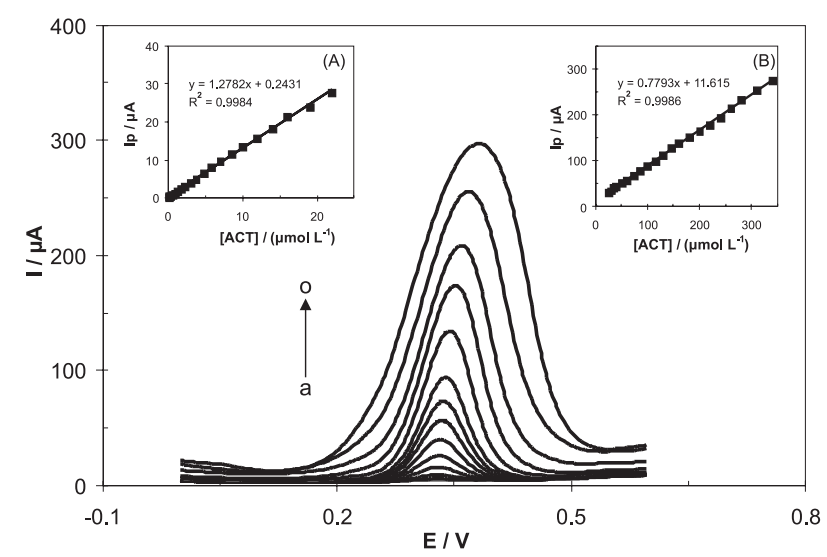

Figure 6. Differential pulse voltammograms for different concentrations of ACT as (a) 0.1, (b) 1.25, (c) 3.75, (d) 8.5, (e) 16, (f) 30, (g) 50, (h) 75, (i) 100 , (j) 130, , (k) 145, (l) 200, (m) 240, (n) 280 and (o) $340 \mu \mathrm{mol} \mathrm{L}-1$. Insets (A) and (B) show plots of corresponding ACT oxidation peak currents as a function of ACT concentrations.

Figure 7 displays hydrodynamic chronoamperograms response of the rotated modified electrode (2500 rpm) with successive injection of ACT at an applied potential of $0.4 \mathrm{~V}$ in PBS ( $\mathrm{pH} 7$ ). Application of chronoamperometry method showed that the linear dynamic range was from 0.3 to $340 \mu \mathrm{mol} \mathrm{L} \mathrm{L}^{-1}$, with a calibration equation of $\mathrm{Ip}(\mu \mathrm{A})=0.3254 \mathrm{c}\left(\mu \mathrm{mol} \mathrm{L} \mathrm{L}^{-1}\right)+2.6513\left(\mathrm{R}^{2}=0.9995\right) . \mathrm{A}$ detection limit of $0.045 \mu \mathrm{mol} \mathrm{L}^{-1}(\mathrm{~S} / \mathrm{N}=3)$ was obtained.

\section{Repeatability and long-term stability of the electrode}

The repeatability of the analytical method for determination of ACT has been studied using DPV method. 

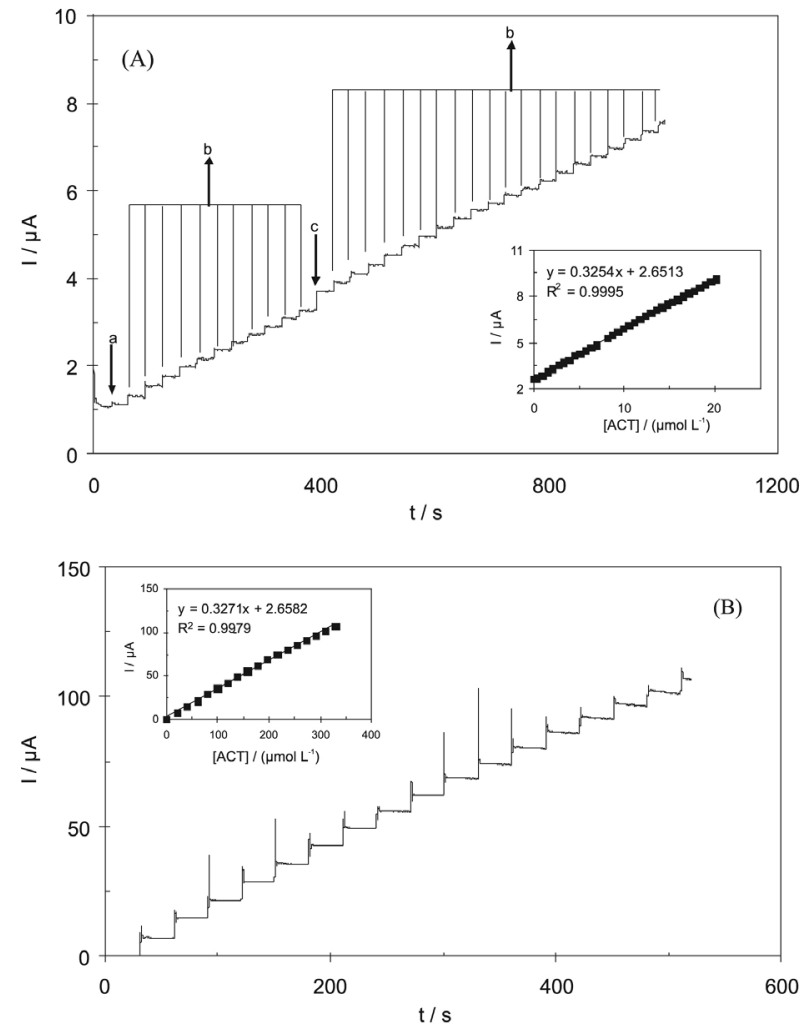

Figure 7. Hydrodynamic amperometric response at rotating MWCNTs/ GCE (rotating speed $2500 \mathrm{rpm}$ ) held at $0.4 \mathrm{~V}$ in PBS (pH 7) for determination of ACT as (A) from 0.3 to $20 \mu \mathrm{mol} \mathrm{L}^{-1}$ by successive additions of (a) 0.3 , (b) 0.6 and (c) $1.2 \mu \mathrm{mol} \mathrm{L} \mathrm{L}^{-1} \mathrm{ACT}$ (inset: corresponding calibration curve), and (B) from 20 to $340 \mu \mathrm{mol} \mathrm{L}^{-1}$ by successive additions of $20 \mu \mathrm{mol} \mathrm{L} \mathrm{L}^{-1}$ ACT (inset: corresponding calibration curve).

Indeed, the relative standard deviations (RSD) of $2.06 \%$ and $1.82 \%$ for 10.0 and $50.0 \mu \mathrm{mol} \mathrm{L}{ }^{-1} \mathrm{ACT}$ over ten consecutive determinations have been obtained, respectively.

Another advantage of the proposed modified electrode is that the resulting modified electrode has a good longterm stability. Stability of the proposed electrode was tested by measuring the decrease in voltammetric current during repetitive DPV measurements of ACT solutions with MWCNTs/GCE stored in solution or air for certain period of time. For example, in the determination of $50 \mu \mathrm{mol} \mathrm{L}^{-1}$ ACT in $0.1 \mathrm{~mol} \mathrm{~L}^{-1} \mathrm{PBS}$ ( $\mathrm{pH} 7$ ), subjecting the modified electrode to an experiment every $30 \mathrm{~min}$, led to a less than $7 \%$ decrease in the voltammetric currents after $24 \mathrm{~h}$. When the electrode was stored in the atmosphere for 5 days, the corresponding current responses fell less than $11 \%$ when the electrode subjected to a solution containing $50 \mu \mathrm{mol} \mathrm{L}^{-1}$ ACT.

\section{Interference studies}

The effects of common interfering species solution of $100 \mu \mathrm{mol} \mathrm{L}^{-1}$ ACT under the optimum conditions were investigated. The results showed that concentrations of L-dopa(500), dopamine(500), L-alanin(1000), L-glutamic $\operatorname{acid}(1400)$, uric acid(200), ascorbic $\operatorname{acid}(700)$ and aspartic acid(3500) did not significantly influence the height of the oxidation peak current for ACT. The tolerance limit was defined as the concentrations which give an error of $\leq 10 \%$ in the determination of ACT compound. The data in the brackets are concentration of the interfering species in $\mu \mathrm{mol} \mathrm{L} \mathrm{L}^{-1}$. The results confirm that the proposed method is free from interferences from the most common interferants.

\section{Analytical applications}

The applicability of the method to the determination of ACT content in real samples such as pharmaceutical preparations, or in solutions in human serum or human urine was investigated. The differential pulse voltammograms were obtained by spiking appropriate amounts of ACT in the prepared real solutions using MWCNTs/GCE at optimum conditions as described earlier. The ACT concentrations were obtained by applying the corresponding calibration plot. The recoveries were acceptable, showing that the proposed methods could be efficiently used for the determination of trace amounts of ACT in biological systems and pharmaceutical preparations. The results are presented in Table 1. The linear dynamic range, detection limit, RSD, sensitivity and some real sample analysis of the proposed method were compared with other voltammetric methods for determination of ACT (Table 2). The results show that the proposed method has higher sensitivity, lower detection limit and wide linear dynamic range.

Table 1. Determination of ACT in real samples with MWCNT

\begin{tabular}{lcccc}
\hline Sample & $\begin{array}{c}\text { Added / } \\
\left(\mu \mathrm{mol} \mathrm{L}^{-1}\right)\end{array}$ & $\begin{array}{c}\text { Found }^{\mathrm{a}} / \\
\left(\mu \mathrm{mol} \mathrm{L}^{-1}\right)\end{array}$ & $\begin{array}{c}\text { R.S.D. / } \\
(\%)\end{array}$ & $\begin{array}{c}\text { Recovery / } \\
(\%)\end{array}$ \\
\hline Serum & 0.0 & 0.0 & - & - \\
& 2.0 & 1.96 & 2.8 & 98.0 \\
\hline Urine & 5.0 & 4.87 & 2.3 & 97.4 \\
\hline Tylenol Tablet & 0.0 & 0 & - & - \\
& 5.0 & 4.93 & 1.9 & 98.6 \\
& 10.0 & 9.76 & 2.2 & 97.6 \\
\hline & 10.0 & 42.71 & 2.2 & 101.4 \\
& 20.0 & 52.62 & 1.8 & 99.1 \\
\hline
\end{tabular}

${ }^{a}$ Average of five determinations at optimum conditions. ${ }^{b}$ This amount is equal to $493.7 \mathrm{mg}$ per tablet. 
Table 2. Comparison of merits of voltammetry methods for determination of ACT

\begin{tabular}{|c|c|c|c|c|c|c|c|c|}
\hline \multirow[t]{2}{*}{ Ref. } & \multirow[t]{2}{*}{ Electrode } & \multirow{2}{*}{$\begin{array}{c}\mathrm{LDR} / \\
\left(\mu \mathrm{mol} \mathrm{L}{ }^{-1}\right)\end{array}$} & \multirow{2}{*}{$\begin{array}{c}\text { Sensitivity/ } \\
\left(\mu \mathrm{A} / \mu \mathrm{mol} \mathrm{L}{ }^{-1}\right)\end{array}$} & \multirow{2}{*}{$\begin{array}{c}\text { LOD/ } \\
(\mu \mathrm{mol} \mathrm{L}-1)\end{array}$} & \multirow{2}{*}{$\begin{array}{c}\mathrm{RSD} / \\
(\%)\end{array}$} & \multicolumn{3}{|c|}{ Analysis in } \\
\hline & & & & & & Serum & Urine & Tablets \\
\hline 24 & GC/tetraruthenated porphyrin film & $1-100$ & NR & 0.11 & NR & No & No & No \\
\hline 25 & Boron-doped diamond thin film & $0.5-50$ & 0.022 & 0.01 & 2.2 & No & No & No \\
\hline 26 & $5 \mathrm{H}$ pencile lead & $100-5000$ & 0.004 & NR & 1.3 & Yes & No & No \\
\hline 27 & $\mathrm{CP} /$ crude extract of zucchini & $120-2500$ & NR & 69 & 1.1 & Yes & No & No \\
\hline 28 & $\mathrm{GC} / \mathrm{Cu}(\mathrm{II})$-Conducting Polymer Complex & $20-5000$ & 0.016 & 5 & 2.5 & Yes & No & No \\
\hline 29 & Nanogold/indium tin oxide & $0.2-1500$ & 0.01 & 0.18 & 2.4 & Yes & No & No \\
\hline 30 & $\begin{array}{l}\mathrm{CF} / \text { electrocopolymerized-moleculary } \\
\text { imprinted film }\end{array}$ & $6.5-2000$ & 0.18 & 1.5 & 5.6 & No & No & No \\
\hline 31 & GC/L-Cysteine & $0.2-100$ & 0.25 & 0.05 & 1.5 & Yes & No & Yes \\
\hline 32 & $\mathrm{GC} / \mathrm{C}_{60}$ & $50-1500$ & 0.013 & 50 & NR & Yes & No & Yes \\
\hline 33 & GC & $0.35-100$ & NR & 0.3 & 4.1 & Yes & No & No \\
\hline 34 & Nafion coated GC tubular & $50-500$ & NR & 17 & 3 & Yes & Yes & No \\
\hline 35 & Imprinted $\mathrm{TiO}_{2}$ thin film & $\begin{array}{r}0.8-5 \\
5-80\end{array}$ & 0.308 & 0.2 & 3.3 & No & No & No \\
\hline 36 & GC/SWCNTs-dicetyl phosphate film & $0.1-20$ & NR & 0.04 & 5.5 & Yes & No & No \\
\hline 37 & $\mathrm{Au} / 4$-amino-2-mercaptopyrimidine & $2-4000$ & 0.165 & 0.4 & 2.8 & Yes & No & No \\
\hline 38 & $\begin{array}{c}\text { GC/carbon-coated nickel magnetic } \\
\text { nanoparticles }\end{array}$ & $7.8-110$ & 0.132 & 0.6 & 1.1 & No & No & No \\
\hline 39 & $\begin{array}{l}\text { PG/electrocopolymerized-moleculary } \\
\text { imprinted polypyrrole }\end{array}$ & $\begin{array}{c}5-500 \\
1250-4500\end{array}$ & NR & 0.79 & NR & Yes & No & No \\
\hline 40 & Carbon film resistor & $0.8-500$ & NR & 0.14 & 1.3 & Yes & No & No \\
\hline 41 & GC/zirconium alcoxide porous gel & $19.6-255$ & NR & 0.12 & NR & Yes & No & No \\
\hline 42 & GC/nano- $\mathrm{TiO}_{2} /$ polymer & $12-120$ & 0.05 & 2 & 2.3 & Yes & No & No \\
\hline 43 & Carbon ionic liquid & $1-2000$ & 0.068 & 0.3 & 2.1 & Yes & No & Yes \\
\hline 44 & PPG/MWCNTs & $\begin{array}{c}0.01-0.2 \\
0.2-20\end{array}$ & 1.04 & 0.01 & $\mathrm{NR}$ & Yes & No & No \\
\hline 45 & Boron-doped diamond & $0.5-83$ & 0.57 & 0.49 & $\mathrm{NR}$ & Yes & No & No \\
\hline 46 & Screen-printed & $2.5-1000$ & NR & 0.1 & 2.2 & Yes & No & No \\
\hline This work & GC/MWCNTs & $\begin{array}{c}0.1-22 \\
26-340 \\
\end{array}$ & 1.278 & 0.029 & 1.8 & Yes & Yes & Yes \\
\hline
\end{tabular}

LOD: Limit of Detection; LDR: Linear dynamic range; NR: Not Reported; GC: Glassy Carbon; CP: Carbon Paste; CF: Carbon Fiber; PG: Pencil Graphite; PPG: Plane Pyrolytic Graphite.

\section{Conclusions}

In this paper we introduced a simple method to make a sensor based on multi-walled carbon nanotube modified glassy carbon electrode. We have shown that the application of MWCNTs can increase anodic peak currents by enhancement of electron transfers of ACT compound on the electrode surface. The results indicated that modification of GCE with MWCNT allows the determination of ACT with good sensitivity and selectivity. The electrode showed high stability in repetitive experiments due to high water stability and high mechanical strength of MWCNTs. The effects of potential interferant were studied, and it was found that the proposed procedure is free from interferences of most common interfering compounds. When the procedure was used for the determination of ACT in some real samples like human serum, urine and some drugs, satisfactory results were obtained The simple fabrication procedure, high speed, reproducibility, high stability, wide linear dynamic range, low detection limit and high sensitivity, all suggest that the proposed sensor is an attractive candidate for practical applications.

\section{Acknowledgments}

The authors gratefully acknowledge the support of this work by the Research Council of Arak University. Thanks to Dr. Alan Happer from Canterbury University in New Zealand for his valuable comments.

\section{References}

1. Sweetman, S. C.; The Complete Drug Reference, $33^{\text {rd }}$ ed., Pharmaceutical Press: London, 2002.

2. Anker, A. In Clinical Toxicology; Marx, J., ed.; W.B. Saunders Company: Philadelphia, 2001.

3. Martin, F. L.; McLean, A. E.; Drug Chem. Toxicol. 1998, $21,477$. 
4. Mugford, C. A.; Tarloff, J. B.; Toxicol. Lett. 1997, 93, 15.

5. Nagasawa, H. T.; Shoeman, D. W.; Cohen, J. F.; Rathbun, W. B.; J. Biochem. Toxicol. 1996, 11, 289.

6. Prabakar, S. J. R.; Narayanan, S. S.; Talanta 2007, 72, 1818.

7. Yesilada, A.; Erdogan, H.; Ertan, M.; Anal. Lett. 1991, 24, 129.

8. Zhao, S.; Bai, W.; Yuan, H.; Xiao, D.; Anal. Chim. Acta 2006, 559, 195.

9. Capella-Peiro, M. E.; Bose, D.; Rubert, M. F.; Esteve-Romero, J.; J. Chromatogr., B 2006, 839, 95.

10. Quintino, M. S. M.; Araki, K.; Toma, H. E.; Angnes, L.; Electroanalysis 2002, 14, 1629.

11. Usifoh, C. O.; Adelusi, S. A.; Adebambo, R. F.; Pak. J. Sci. Ind. Res. 2002, 45, 7.

12. Knochen, M.; Giglio, J.; Reis, B. F.; J. Pharm. Biomed. Anal. 2003, 33, 191

13. Al-Zoubi, N.; Koundourellis, J. E.; Malamataris, S.; J. Pharm. Biomed. Anal. 2002, 29, 459.

14. Xiong, X. Y.; Tang, Y. H.; Wang, N. N.; Wu, S. J.; Fenxi Shiyanshi 2007, 26, 80.

15. Silva, M. L. S.; Garcia, M. B. Q.; Lima, J. L. F. C.; Barrado, E.; Portugaliae Electrochim. Acta 2006, 24, 261.

16. Ravisankar, S.; Vasudevan, M.; Gandhimathi, M.; Suresh, B.; Talanta 1998, 46, 1577.

17. Goyal, A.; Jain, S.; Acta Pharm. Sci. 2007, 49, 147.

18. Selvan, P. S.; Gopinath, R.; Saravanan, V. S.; Gopal, N.; Kumar, S. A.; Periyasamy, K.; Asian J. Chem. 2007, 19, 1004.

19. Bouhsain, Z.; Garrigues, S.; de la Guardia, M.; Fresenius J. Anal.Chem. 1997, 357, 973.

20. Hanaee, J.; Pharm. Acta Helv. 1997, 72, 239.

21. Mohamed, F. A.; Abdallah, M. A.; Shammat, S. M.; Talanta 1997, 44, 61.

22. Khaskheli, A. R.; Shah, A.; Bhange, M. I.; Niazr, A.; Mahesar, S.; Spectrochim. Acta, Part A 2007, 68, 747.

23. Easwaramoorthy, D.; Yu, Y. C.; Huang, H. J.; Anal. Chim. Acta 2001, 439, 95

24. Quintino, M. S. M.; Araki, K.; Toma, H. E.; Angnes, L.; Electroanalysis 2002, 14, 1629.

25. Wangfuengkanagul, N.; Chailapakul, O.; J. Pharm. Biomed. Anal. 2002, 28, 841.

26. Masawat, P.; Liawruangrath, S.; Vaneesorn, Y.; Liawruangrath, B.; Talanta 2002, 58, 1221.

27. Vieira, I. C.; Lupetti, K. O.; Fatibello-Filho, O.; Quim. Nova 2003, 26, 39.

28. Boopathi, M.; Won, M. S.; Shim, Y. B.; Anal. Chim. Acta 2004, 512, 191.

29. Goyal, R. N.; Gupta, V. K.; Oyama, M.; Bachheti, N.; Electrochem. Commun. 2005, 7, 803.
30. Gomez-Caballero, A.; Goicolea, M. A.; Barrio, R. J.; Analyst 2005, 130, 1012.

31. Wang, C.; Li, C.; Wang, F.; Wang, C.; Microchim. Acta 2006, 155, 365 .

32. Goyal Rajendra, N.; Singh Sudhanshu, P.; Electrochim. Acta 2006, 51, 3008.

33. Messina, G. A.; De Vito, I. E.; Raba, J.; Anal. Chim. Acta 2006, 559, 152.

34. Silva, M. L. S.; Garcia, M. B. Q.; Lima, J. L. F. C.; Barrado, E.; Anal. Chim. Acta 2006, 573, 383.

35. Wang, C.; Li, C.; Wei, L.; Wang, C.; Microchim. Acta 2007, $158,307$.

36. Sun, D.; Zhang, H.; Microchim. Acta 2007, 158, 131.

37. Jia, L.; Zhang, X. H.; Li, Q.; Wang, S. F.; Anal. Chem. 2007, $62,266$.

38. Wang, S. F.; Xie, F.; Hu, R. F.; Sens. Actuators, B 2007, 123, 495.

39. Ozcan, L.; Sahin, Y.; Sens. Actuators, B 2007, 127, 362.

40. Felix, F. S.; Brett, C. M. A.; Angnes, L.; J. Pharm. Biomed. Anal. 2007, 43, 1622.

41. Sima, V.; Cristea, C.; Lapadus, F.; Marian, I. O.; Marian, A.; Sandulescu, R.; J. Pharm. Biomed. Anal. 2008, 48, 1195.

42. Ashok kumar, S.; Chun-Fang Tang; Shen-Ming Chen; Talanta 2008, 76, 997.

43. ShangGuan, X.; Zhang, H.; Zheng, J.; Anal. Bioanal. Chem. 2008, 391, 1049.

44. Kachoosangi, R. T.; Wildgoose, G. G.; Compton, R. G.; Anal. Chim. Acta 2008, 618, 54.

45. Lourencao, B. C.; Medeiros, R. A.; Rocha-Filho, R. C.; Mazo, L. H.; Fatibello-Filho, O.; Talanta 2009, 78, 748.

46. Fanjul-Bolado, P.; Lamas-Ardisana, P. J.; Hernandez-Santos, D.; Costa-Garcia, A.; Anal. Chim. Acta 2009, 638, 133.

47. Rao, C. N. R.; Satishkumar, B. C.; Govindaraj, A.; Nath, M.; Chem. Phys. Chem. 2001, 2, 78.

48. Baughman, R. H.; Zakhidov, A. A.; de Heer, W. A.; Science 2002, 297, 787.

49. Laviron, E.; J. Electroanal. Chem. 1979, 101, 19.

50. Miner, D. J.; Rice, J. R.; Riggin, R. M.; Kissinger, P. T.; Anal. Chem. 1981, 53, 2258.

51. Gilmartin, M. A. T.; Hart, J. P.; Analyst 1994, 119, 2431.

52. Felix, F. S.; Brett, C. M. A.; Angnes, L.; J. Pharm. Biomed. Anal. 2007, 43, 1622.

Submitted: April 5, 2010 Published online: October 14, 2010 